\title{
Foraging Behaviour of Major Pollinators in Bitter Gourd
}

\author{
A. Yogapriya ${ }^{1}$, B. Usharani ${ }^{2}$, K. Suresh ${ }^{1}$, S. Vellaikumar ${ }^{3}$ and C. Chinniah ${ }^{1}$ \\ ${ }^{1}$ Department of Agricultural Entomology, ${ }^{2} I C A R-K V K,{ }^{3}$ Department of Biotechnology, \\ Agricultural College and Research Institute, TNAU, Madurai - 625104, Tamil Nadu, India \\ *Corresponding author
}

\begin{abstract}
A B S T R A C T
\section{Keywords}

Apiculture, Bitter

gourd, Foraging

activities,

Pollinators

Article Info

Accepted:

10 May 2019

Available Online:

10 June 2019

Field experiments were conducted to record the diversity of floral visitors/pollinators in Bitter gourd Kharif season, 2018, with three replications. The experimental plot was kept free from chemical sprays during the flowering period. Insects belonging to various orders like Hymenoptera, Lepidoptera, Diptera, Hemiptera and Coleoptera were found visiting the bitter gourd flowers. Major pollinators of bitter gourd have been identified by their foraging activity. Foraging behaviour of major pollinators were recorded during different hours of the day viz. 0600 to $1800 \mathrm{~h}$ based on No. of individuals $/ 5 \mathrm{~min} / \mathrm{m}^{2}$, Time spent by one individual $(\mathrm{sec})$ on each flower, No. of flowers visited by one individual $/ 5 \mathrm{~min}$ and No. of individuals visited per flower $/ 5 \mathrm{~min}$. Insects foraging on pollen and nectar from the flower were also recorded. From the above observations it was found that the bees forage on bitter gourd flowers very actively from 0600 to 1600 hours at a varying level.
\end{abstract}

\section{Introduction}

Momordica charantia is a tropical and subtropical vine of the family Cucurbitaceae, widely grown in Asia, Africa, and the Caribbean for its edible fruit. Its pods (fruits) are rich sources of phytonutrients like dietary fiber, minerals, vitamins, and anti-oxidants. Bitter melon notably contains phytonutrient, polypeptide-P and plant insulin known to lower blood sugar levels. Also, it composes hypoglycemic agent called Charantin. Charantin increases glucose uptake and glycogen synthesis inside the cells of the liver, muscle, and fatty (adipose) tissue. Together, these compounds may have been thought to be responsible for blood sugar levels reduction in the treatment of type- 2 diabetes. Fresh pods are the excellent source of folates, carrying about $72 \mu \mathrm{g} / 100 \mathrm{~g}$ ( $18 \%$ of RDA). Vitamin folate when taken by mothers during their early pregnancy time would help reduce the incidence of neural tube defects in the newborn babies.

Fresh fruit of bitter gourd is an excellent source of vitamin-C (100 grams of fresh pod provides $84 \mathrm{mg}$ or about $140 \%$ of RDI). Vitamin-C is one of the powerful natural antioxidants which helps scavenge harmful free radicals from the human body. Further, it is an excellent source of health benefiting 
flavonoids such as $\beta$-carotene, $\alpha$-carotene, lutein, and zea-xanthin. It also contains a good amount of vitamin-A. Together, these compounds help act as protective scavengers against oxygen-derived free radicals and reactive oxygen species (ROS) that play a role in aging, cancers and various disease processes. Bitter melon stimulates smooth digestion and peristalsis of food through the bowel until it excreted from the body. Thus, it helps in relieving indigestion and constipation problems. Further, it has small amounts of Bcomplex vitamins such as niacin (vitamin B3), pantothenic acid (vitamin B-5), pyridoxine (vitamin B-6) and minerals such as iron, zinc, potassium, manganese and magnesium (USDA National Nutrient data base).

Pollination is a problem in cucurbits because of the Monoecious flowering habit. The bitter gourd flowers starts opening at 0300 hours of the day and open fully at 0530 hours to 1200huors. The yield of the crop varies widely due to the pollination gap than fertilizer and pest related problems (Motzke et al., 2015). Male: Female flower ratio will be 25:1 (Palada and Chang, 2003) and 19:1 (Deyto and Cervancia, 2009). Male flowers bloom two weeks earlier to female flowers during long days and vice versa during short days. Spraying flowering hormones to increase the number of flowers and therefore the fruits can increase the yield, but pollination of the flowers is challenging. Any material to increase the visit of pollinators can have greater impact on harnessing pollination (Viraktamath and Anagoudar, 2002). The present experiment was performed to study the pollinator activity in bitter gourd therefore to take-up necessary actions to improve pollination by increasing pollinator activity.

\section{Materials and Methods}

Periodical field survey was conducted at weekly intervals during Kharif, 2018, with three replications. The experimental plot was kept free from chemical sprays during the flowering period. The diversity of floral visitors/ pollinators of bitter gourd were recorded in five randomly selected one square meter area during flowering period at 0600 0800, 0800 - 1000, 1000 - 1200, 1200 - 1400, 1400 - 1600 and $1600-1800 \mathrm{~h}$ for five minutes. The data were later averaged timewise and group-wise to infer the pollinator fauna as well as the dominance of particular group. Foraging behaviour of major pollinators of bitter gourd were recorded based on No. of individuals $/ 5 \mathrm{~min} / \mathrm{m}^{2}$, Time spent by one individual (sec) in each flower, No. of flowers visited by one individual $/ 5 \mathrm{~min}$ and No. of individuals visited per flower/5min. Insects foraging on pollen and nectar from the flower have also been recorded by observing the foraging activity of the insect visually to know the role of the flower visitors in pollination service. Honeybees with their activity of extending their proboscis into the flowers are considered as nectar collectors and bees carrying pollen on their hind legs were determined as pollen collectors (Balachandra et al., 2014).

\section{Statistical analysis}

The mean values were square root transformed and compared by Least Significant Difference (LSD) at 5 per cent probability with AGRES to assess the effective pollinator at different hours.

\section{Results and Discussion}

Insects belonging to various orders like Hymenoptera, Lepidoptera, Diptera, Hemiptera and Coleoptera (Table 1) were found visiting bitter gourd flowers during the study period where hymenopterans dominated other floral visitors. Foraging behaviour of major hymenopteran pollinators are discussed in this paper with a view of acquiring more 
knowledge about the pollinator activity in bitter gourd ecosystem and to take-up pest control activities accordingly.

T. iridipennis was the major pollinator of bitter gourd with an abundance of 2.78 individuals $/ 5 \mathrm{~min} / \mathrm{m}^{2}$ followed by $A$. florea (1.46), Halictus sp (1.02) and A. cerana indica (0.90) (Fig1).

Time spent by every individual in each flower (average) varies as 48.12 seconds in $T$. iridipennis, while it was 25.42 seconds in $A$. florea and 18.25 seconds in Halictus sp. followed by 3.91 seconds in A. cerana indica (Fig1).

Also the average number of flowers visited by one individual was chief with 5.56 by $T$. iridipennis, followed by A. florea, A. cerana indica and Halictus sp. with 4.12, 3.95 and 3.17 respectively, which shows the swiftness of Indian bees (A. cerana indica) as a pollinator. No. of bees visiting one flower in 5 min (mean) ranged from 0.86 in Halictus sp. to 2.99 in T.iridipennis and 1.70, 1.48 in $A$. floraea and $A$. cerana indica (Fig1).

The activity of $T$. iridipennis was maximum during $0600-1200 \mathrm{~h}$ where the no. of individuals $/ 5 \mathrm{~min} / \mathrm{m}^{2}$, time spent by one individual ( $\mathrm{sec}$ ) in each flower and no. of flowers visited by one individual $/ 5 \mathrm{~min}$ were maximum with a peak activity during 0600 0800h. Abundance of T. iridipennis was in the order 5.29, 6.26 and 3.28 during $0600-0800$, $0800-1000$ and $1000-1200 \mathrm{~h}$ respectively (Table 2). Average time spent by one individual per flower during the peak hours was in the range $118.64(\mathrm{sec}), 6364(\mathrm{sec})$ and $56.56(\mathrm{sec})$ respectively (Table 3 ). While the no. of flowers visited by one individual $/ 5 \mathrm{~min}$ was at the maximum at all hours with 4.67 , $5.67,16.67,14.0,6.0$ and 3.0 flowers at 0600 - 0800, $0800-1000,1000-1200,1200-$ $1400,1400-1600$ and $1600-1800$ h one by one (Table 4). No. of bees visiting one flower in $5 \mathrm{~min}$ was 5.70 in $0600-0800 \mathrm{~h}$ and 5.50 at $0800-1000 \mathrm{~h}$ (both on par) followed by 3.27 and 2.23 from $1000-1200$ and $1200-1400 \mathrm{~h}$ respectively (on par). No. of bees visiting a single flower was minimum during 1400 1600 and $1600-1800$ with 1.00 and 0.23 bees respectively (on par) (Table 5).

A. florea exhibited high pollinating (foraging) activity right from 0900 to 1600 hours with highest activity during $1000-1200 \mathrm{~h}$ followed by $1200-1400 \mathrm{~h}$ which extends up-to 1600 with a slight decrease after $1400 \mathrm{~h}$. During the peak foraging periods the abundance of $A$. florea was 5.02, 2.86 and 0.58 individually at $1000-1200,1200-1400 \mathrm{~h}$ and $1400-1600$ hours (Table 2). While the average time spent by one individual per flower was $46.00(\mathrm{sec})$ at $1000-1200 \mathrm{~h}, 52.00(\mathrm{sec})$ at $1200-1400 \mathrm{~h}$ (on par) and 28.00 and $26.32(\mathrm{sec})$ during $0800-1000$ (selectively after 0930h) and 1400 - 1600 hours (Table 3). Number of flowers visited on an average by one individual was 10.0 at $1000-1200 \mathrm{~h}$ and 7.34 at $1200-1400$ hours which represents the peak foraging periods of A. florea. Bitter gourd flowers attracted maximum no. of little bees during $1000-1200$ and $1200-1400 \mathrm{~h}$ (4.1 and 3.83) (Table 4). Whereas number of bees visiting bitter gourd flowers at $0800-$ $1000 \mathrm{~h}$ was 1.17 and 1.07 during $1400-1600$ hours (Table 5).

Regarding A. cerana indica abundance, average time spent per flower and number of flowers visited was maximum at 0600 $0800 \mathrm{~h}$, while the time spent were on par for $0600-0800$ and $0800-1000 \mathrm{~h}$. The abundance was at the maximum at $0600-$ 0800h (2.48) (Table 2), while the time spent was on par between $0600-0800 \mathrm{~h}$ and $0800-$ 1000h (9.01 and 8.12 seconds), slightly decreasing during 1000 - 1200 (3.83 seconds) hours (Table 3). Number of flower visited was in the peak during $0600-0800 \mathrm{~h}$ with 
10.66 flowers and on par from 0800 to 1200 hours with 6.34 and 4.0 flowers for 0800 $1000 \mathrm{~h}$ and $1000-1200 \mathrm{~h}$ (Table 4). Bitter gourd lured 3.67 and 3.17 bees from $0600-$ 0800 and $0800-1000 \mathrm{~h}$ respectively (Table $5)$. While number of bees visiting bitter gourd flowers was reduced to 1.17 in $1000-1200 \mathrm{~h}$, 0.5 in $1200-1400 \mathrm{~h}$ and 0.34 during $1400-$ 1600h (Table 5). Thus, the Indian bees ( $A$. cerana indica) act as an effective pollinator of bitter gourd from $0600-1000$ hours.

Abundance of Halictus sp. was maximum (2.73) at $1000-1200$ hours followed by 1.41 during $0800-1000 \mathrm{~h}$ (Table 2). Time spent per flower was higher from $0800 \mathrm{~h}$ to $1200 \mathrm{~h}$ with 42.42 and 38.32 seconds followed by 22.23 seconds during $1200-1400$ hours (Table 3). However the number of flowers visited was on par from 0800 to 1400 hours (5.00, 6.00 and 4.67) (Table 4) and number of bees visiting bitter gourd flowers was higher
1.63 and 1.60 at $1000-1200$ and $1200-$ $1400 \mathrm{~h}$ followed by 1.10 in $0800-1000 \mathrm{~h}$ and 0.77 in $1400-1600$ hours (Table 5).

The results of our experiment are in accordance with the findings of (Subhakar et al., 2013) who reported that Trigona iridipennnis, Halictus guttuorosus and Apis florae as major pollinator of bitter gourd among the 14 species of pollinators recorded. Six hymenopterans, five Lepidopterans and three Dipterans were recorded pollinating bitter gourd flowers by (Subhakar et al., 2013).

Further our findings are also in line with (Mann, 1953; Mcgregor et al., 1950; Mcgregor and Todd, 1952; Mcgregor, 1965) who reported that bee activity in cantaloupe flowers reaches its peak during 1100 and 1200 hours while it opens shortly after 0700 0800 and becomes scanty in late afternoon.

Table.1 List of major pollinators in bitter gourd and their role as pollinators

\begin{tabular}{|c|c|c|c|c|}
\hline \multirow[t]{2}{*}{ S.no. } & \multirow[t]{2}{*}{ POLLINATORS } & \multirow[t]{2}{*}{ FAMILY } & \multicolumn{2}{|c|}{ ROLE } \\
\hline & & & Pollen & Nectar \\
\hline \multicolumn{5}{|c|}{ Hymenoptera } \\
\hline 1. & Apis cerana indica Fab & Apidae & + & + \\
\hline 2. & Apis dorsata Fab & Apidae & + & + \\
\hline 3. & Apis florea Fab & Apidae & + & + \\
\hline 4. & $\begin{array}{l}\text { Tetragonula iridipennis } \\
\text { Smith }\end{array}$ & Apidae & + & + \\
\hline 5. & Amegilla zonata $\mathrm{L}$ & Apidae & + & + \\
\hline 6. & Xylocopa violacea $\mathrm{L}$ & Xylocopidae & + & + \\
\hline 7. & Halictus sp. & Halicitidae & + & + \\
\hline \multicolumn{5}{|c|}{ Diptera } \\
\hline 8. & Syrphus ribesii L & Syrphidae & - & + \\
\hline \multicolumn{5}{|c|}{ Lepidoptera } \\
\hline 9. & Danaius chrysippus L & Nymphalidae & - & + \\
\hline 10. & $\begin{array}{l}\text { Tirumala limniace } \\
\text { Cramer }\end{array}$ & Nymphalidae & - & + \\
\hline \multicolumn{5}{|c|}{ Coleoptera } \\
\hline 11. & Aulacophora sp. & Chrysomelidae & - & + \\
\hline
\end{tabular}


Table.2 Abundance of major pollinators in bitter gourd flowers

\begin{tabular}{|c|c|c|c|c|}
\hline \multirow{2}{*}{ Time (hours) } & \multicolumn{4}{|c|}{ No. of individuals/5min/m $\mathbf{m}^{2}$} \\
\cline { 2 - 5 } & A. cerana indica & A. florae & T.iridipennis & Halictus $\mathrm{sp}$. \\
\hline $\mathbf{0 6 0 0}-\mathbf{0 8 0 0}$ & 2.48 & $0.00 \mathrm{e}$ & 5.29 & 0.00 \\
& $(1.73)^{\mathrm{a}}$ & $(0.71)^{\mathrm{e}}$ & $(2.30)^{\mathrm{ab}}$ & $(0.71)^{\mathrm{e}}$ \\
\hline $\mathbf{0 8 0 0}-\mathbf{1 0 0 0}$ & 2.13 & 0.28 & 6.26 & 1.41 \\
& $(1.62)^{\mathrm{b}}$ & $(0.88)^{\mathrm{d}}$ & $(2.50)^{\mathrm{ab}}$ & $(1.38)^{\mathrm{b}}$ \\
\hline $\mathbf{1 0 0 0}-\mathbf{1 2 0 0}$ & 0.72 & 5.02 & 3.28 & 2.73 \\
& $(1.10)^{\mathrm{c}}$ & $(2.34)^{\mathrm{a}}$ & $(1.81)^{\mathrm{a}}$ & $(1.80)^{\mathrm{a}}$ \\
\hline $\mathbf{1 2 0 0}-\mathbf{1 4 0 0}$ & 0.02 & 2.86 & 1.46 & 1.34 \\
\hline $\mathbf{1 4 0 0}-\mathbf{1 6 0 0}$ & $(0.72)^{\mathrm{d}}$ & $(1.83)^{\mathrm{b}}$ & $(1.21)^{\mathrm{bc}}$ & $(1.35)^{\mathrm{c}}$ \\
\hline & 0.02 & 0.58 & 0.24 & 0.62 \\
\hline $\mathbf{1 6 0 0}-\mathbf{1 8 0 0}$ & $(0.72)^{\mathrm{d}}$ & $(1.04)^{\mathrm{c}}$ & $(0.49)^{\mathrm{c}}$ & $(1.05)^{\mathrm{d}}$ \\
\hline S.Ed & 0.00 & 0.00 & 0.16 & 0.00 \\
\hline CD $(\mathbf{0 . 0 5})$ & $(0.71)^{\mathrm{d}}$ & $(0.71)^{\mathrm{e}}$ & $(0.40)^{\mathrm{c}}$ & $(0.71)^{\mathrm{e}}$ \\
\hline
\end{tabular}

*Each value is a mean of twenty one week observation.

Figures in parenthesis are square root transformed values

In a column, means followed by same letter(s) are on par by LSD $(p=0.05)$

Table.3 Time spent by major pollinators of bitter gourd in each flower

\begin{tabular}{|c|c|c|c|c|}
\hline \multirow{2}{*}{ Time (hours) } & \multicolumn{4}{|c|}{ Time spent by an individual(sec) in each flower } \\
\cline { 2 - 5 } & A. cerana indica & A. florae & T.iridipennis & Halictus sp. \\
\hline $\mathbf{0 6 0 0}-\mathbf{0 8 0 0}$ & 9.01 & 0.00 & 118.64 & 0.00 \\
& $(3.08)^{\mathrm{a}}$ & $(0.71)^{\mathrm{c}}$ & $(10.92)^{\mathrm{a}}$ & $(0.71)^{\mathrm{e}}$ \\
\hline $\mathbf{0 8 0 0}-\mathbf{1 0 0 0}$ & 8.12 & 28.00 & 63.64 & 42.42 \\
& $(3.07)^{\mathrm{a}}$ & $(5.34)^{\mathrm{b}}$ & $(8.01)^{\mathrm{b}}$ & $(6.55)^{\mathrm{a}}$ \\
\hline $\mathbf{1 0 0 0}-\mathbf{1 2 0 0}$ & 3.83 & 46.00 & 56.56 & 38.32 \\
& $(2.08)^{\mathrm{b}}$ & $(6.82)^{\mathrm{a}}$ & $(7.56)^{\mathrm{b}}$ & $(6.23)^{\mathrm{b}}$ \\
\hline $\mathbf{1 2 0 0}-\mathbf{1 4 0 0}$ & 1.33 & 52.20 & 32.32 & 22.23 \\
\hline $\mathbf{1 4 0 0}-\mathbf{1 6 0 0}$ & $(1.35)^{\mathrm{c}}$ & $(7.23)^{\mathrm{a}}$ & $(5.73)^{\mathrm{c}}$ & $(4.77)^{\mathrm{c}}$ \\
\hline & 1.17 & 26.32 & 14.28 & 06.52 \\
\hline $\mathbf{1 6 0 0}-\mathbf{1 8 0 0}$ & $(1.29)^{\mathrm{c}}$ & $(5.18)^{\mathrm{b}}$ & $(3.84)^{\mathrm{d}}$ & $(2.65)^{\mathrm{d}}$ \\
\hline & 0.00 & 0.00 & 03.26 & 0.00 \\
\hline S.Ed & $(0.71)^{\mathrm{d}}$ & $(0.71)^{\mathrm{c}}$ & $(1.93)^{\mathrm{e}}$ & $(0.71)^{\mathrm{e}}$ \\
\hline CD $(\mathbf{0 . 0 5})$ & 0.1693 & 0.2363 & 0.8086 & 0.0321 \\
\hline
\end{tabular}

*Each value is a mean of twenty one week observation.

Figures in parenthesis are square root transformed values

In a column, means followed by same letter(s) are on par by LSD $(\mathrm{p}=0.05)$ 
Table.4 No. of flowers visited by one individual $/ 5 \mathrm{~min}$ in bitter gourd flowers

\begin{tabular}{|c|c|c|c|c|}
\hline \multirow[t]{2}{*}{ Time (hours) } & \multicolumn{4}{|c|}{ No. of flowers visited by an individual $/ 5 \mathrm{~min}$} \\
\hline & A. cerana indica & A. florae & T.iridipennis & Halictus sp. \\
\hline $0600-0800$ & $\begin{array}{c}10.66 \\
(3.27)^{\mathrm{a}}\end{array}$ & $\begin{array}{c}0.00 \\
(0.71)^{\mathrm{d}}\end{array}$ & $\begin{array}{c}4.67 \\
(2.27)^{\mathrm{b}}\end{array}$ & $\begin{array}{c}0.00 \\
(0.71)^{\mathrm{c}}\end{array}$ \\
\hline $0800-1000$ & $\begin{array}{c}6.34 \\
(2.62)^{\mathrm{b}}\end{array}$ & $\begin{array}{c}04.34 \\
(2.20)^{\mathrm{c}}\end{array}$ & $\begin{array}{c}5.67 \\
(2.48)^{\mathrm{b}}\end{array}$ & $\begin{array}{c}5.0 \\
(2.35)^{\mathrm{a}}\end{array}$ \\
\hline $1000-1200$ & $\begin{array}{c}4.0 \\
(2.12)^{\mathrm{b}}\end{array}$ & $\begin{array}{c}10.0 \\
(3.24)^{\mathrm{a}}\end{array}$ & $\begin{array}{c}16.67 \\
(4.14)^{\mathrm{a}}\end{array}$ & $\begin{array}{c}06.00 \\
(2.55)^{\mathrm{a}}\end{array}$ \\
\hline $1200-1400$ & $\begin{array}{c}1.5 \\
(1.41) \mathrm{c}\end{array}$ & $\begin{array}{c}7.34 \\
(2.80)^{\mathrm{b}}\end{array}$ & $\begin{array}{c}14.0 \\
(3.81)^{\mathrm{a}}\end{array}$ & $\begin{array}{c}4.67 \\
(2.27)^{\mathrm{a}}\end{array}$ \\
\hline $1400-1600$ & $\begin{array}{c}1.17 \\
(1.29)^{\mathrm{c}}\end{array}$ & $\begin{array}{c}3.0 \\
(1.87)^{\mathrm{c}}\end{array}$ & $\begin{array}{c}6.0 \\
(2.55)^{\mathrm{b}}\end{array}$ & $\begin{array}{c}3.34 \\
(1.96)^{b}\end{array}$ \\
\hline $1600-1800$ & $\begin{array}{c}00.00 \\
(0.71)^{d}\end{array}$ & $\begin{array}{c}0.00 \\
(0.71)^{\mathrm{d}}\end{array}$ & $\begin{array}{c}3.0 \\
(1.87)^{\mathrm{b}}\end{array}$ & $\begin{array}{c}0.00 \\
(0.71)^{\mathrm{c}}\end{array}$ \\
\hline Mean & 3.95 & 4.12 & 5.56 & 3.17 \\
\hline S.Ed & 0.2262 & 0.1549 & 0.3448 & 0.1624 \\
\hline CD (0.05) & 0.5040 & 0.3452 & 0.7683 & 0.3619 \\
\hline
\end{tabular}

*Each value is a mean of twenty one week observation.

Figures in parenthesis are square root transformed values

In a column, means followed by same letter(s) are on par by LSD $(p=0.05)$

Table.5 No. of individuals of major pollinators each flower received $/ 5 \mathrm{~min}$

\begin{tabular}{|c|c|c|c|c|}
\hline \multirow[t]{2}{*}{ Time (hours) } & \multicolumn{4}{|c|}{ No. of individuals visited per flower $/ 5 \mathrm{~min}$} \\
\hline & A. cerana indica & A. florae & T.iridipennis & Halictus sp \\
\hline $0600-0800$ & $\begin{array}{c}3.67 \\
(2.04)^{\mathrm{a}}\end{array}$ & $\begin{array}{c}0.00 \\
(0.71)^{\mathrm{b}}\end{array}$ & $\begin{array}{c}5.70 \\
(2.49)^{\mathrm{a}}\end{array}$ & $\begin{array}{c}0.00 \\
(0.71)^{\mathrm{b}}\end{array}$ \\
\hline $0800-1000$ & $\begin{array}{c}3.17 \\
(1.91)^{\mathrm{a}}\end{array}$ & $\begin{array}{c}1.17 \\
(1.29)^{b}\end{array}$ & $\begin{array}{c}5.50 \\
(2.45)^{\mathrm{a}}\end{array}$ & $\begin{array}{c}1.10 \\
(1.26)^{\mathrm{a}}\end{array}$ \\
\hline $1000-1200$ & $\begin{array}{c}1.17 \\
(1.29)^{b}\end{array}$ & $\begin{array}{c}4.1 \\
(2.14)^{\mathrm{a}}\end{array}$ & $\begin{array}{c}3.27 \\
(1.94)^{b}\end{array}$ & $\begin{array}{c}1.63 \\
(1.46)^{\mathrm{a}}\end{array}$ \\
\hline $1200-1400$ & $\begin{array}{c}0.5 \\
(1.0)^{\mathrm{c}}\end{array}$ & $\begin{array}{c}3.83 \\
(2.08)^{\mathrm{a}}\end{array}$ & $\begin{array}{c}2.23 \\
(1.65)^{\mathrm{b}}\end{array}$ & $\begin{array}{c}1.60 \\
(1.45)^{\mathrm{a}}\end{array}$ \\
\hline $1400-1600$ & $\begin{array}{c}0.34 \\
(0.91)^{\mathrm{c}}\end{array}$ & $\begin{array}{c}1.07 \\
(1.25)^{\mathrm{b}}\end{array}$ & $\begin{array}{c}1.00 \\
(1.224)^{\mathrm{c}}\end{array}$ & $\begin{array}{c}0.77 \\
(1.13)^{\mathrm{ab}}\end{array}$ \\
\hline $1600-1800$ & $\begin{array}{c}0.00 \\
(0.71)^{\mathrm{c}}\end{array}$ & $\begin{array}{c}0.001 \\
(0.71)^{b}\end{array}$ & $\begin{array}{c}0.23 \\
(0.85)^{\mathrm{c}}\end{array}$ & $\begin{array}{c}0.00 \\
(0.72)^{\mathrm{b}}\end{array}$ \\
\hline S.Ed & 0.1917 & 0.2498 & 0.1820 & 0.2041 \\
\hline CD (0.05) & 0.4271 & 0.5566 & 0.4055 & 0.4548 \\
\hline
\end{tabular}

*Each value is a mean of twenty one week observation.

Figures in parenthesis are square root transformed values

In a column, means followed by same letter(s) are on par by LSD $(\mathrm{p}=0.05)$ 
Fig.1 Foraging behaviour of major pollinators in bitter gourd

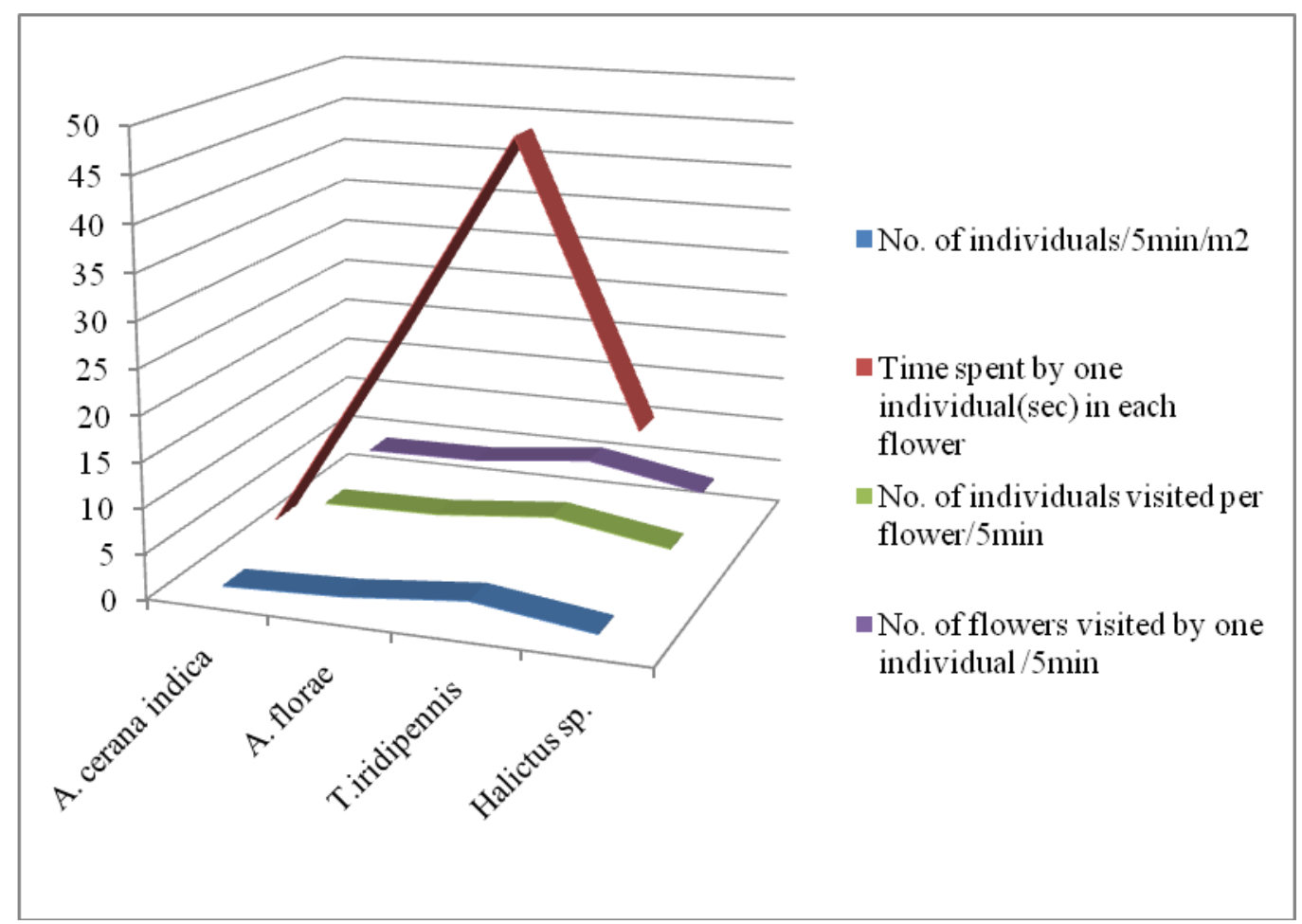

Our results are in accordance with the reports of (Nidagundi and Sattagi, 2005) who observed the foraging activity of bees on bitter gourd was observed from 08:00 hours to 18:00 hours of the day, during 10 percent flowering. Foraging activity $A$. dorsata and $A$. florea were observed from 08:00 to 18:00 h of the day, with the highest foraging activity at 12:00 h with 6.68 and 15.44 bees $/ \mathrm{m}^{2} / 5 \mathrm{~min}$., respectively. But, Apis cerana and other pollinators foraging activity was maximum at 10:00 hours, with 12.51 bees $/ \mathrm{m}^{2} / 5 \mathrm{~min}$. and 6.39 pollinators $/ \mathrm{m}^{2} / 5 \mathrm{~min}$.

From our findings it is clear that the activity of major pollinators falls between 0600 hours and 1400 hours. Farmers should take care to increase the activities of pollinators and perform agronomic practices accordingly. Our suggestion from this experiment is that pest control measures should be taken after 1600 hours in order to safeguard the pollinating insect species from the adverse effect of insecticidal applications, since the number of bees visiting the flowers by major pollinators is maximum till $1600 \mathrm{~h}$. Moreover use of inorganic chemicals in bitter gourd pest control is not advisable. Use of phytoinsecticides prepared from plant leaves and organic formulations like NSKE, Neem Oil and Chilli-Garlic extract which are found to be safer to honey bees are advisable in bitter gourd pest control.

\section{References}

Bhalchandra. W., R.K. Baviskar and T. B. Nikam. 2014. Diversity of nectariferous and polleniferous bee flora at Anjaneri and Dugarwadi hills of Western Ghats of Nasik district (M. S.) India. Journal of Entomology and Zoology Studies, 2 (4): 244-249.

Deyto, R. C., and Cervancia, C. R. (2009). Floral biology and pollination of Ampalaya (Momordica charantia L.). Philippine Agricultural Scientist, 92(1), 8-18. 
Mann, L. K. (1953). Honey bee activity in relation to pollination and fruit set in the cantaloupe (Cucumis melo). American Journal of Botany, 40(7), 545-553.

Mcgregor, S., Levin, M., and Foster, R. E. (1965). Honey bee visitors and fruit set of cantaloups. Journal of Economic Entomology, 58(5), 968-970.

Mcgregor, S., and Todd, F. E. (1952). Cantaloup production with honey bees. Journal of economic entomology, 45(1), 43-47.

Mcgregor, S. E. (1950). SE, 1950, Activity of honeybees on cantaloupe. Rep. Lowa. St. Apiarist, 140-142.

Motzke, I., Tscharntke, T., Wanger, T. C., and Klein, A. M. (2015). Pollination mitigates cucumber yield gaps more than pesticide and fertilizer use in tropical smallholder gardens. Journal of applied ecology, 52(1), 261-269.
Nidagundi, B. R., and Sattagi, H. N. (2005). Pollinator fauna and foraging activity of bees in bitter gourd. Karnataka Journal of Agricultural Sciences, 18(4), 682985.

Palada, M., and Chang, L. (2003). Suggested cultural practices for bitter gourd. AVRDC International Cooperators' Guide, 03-547.

Subhakar, G., Sreedevi, K., Manjula, K., and Reddy, N. E. (2013). Pollinator diversity and abundance in bitter gourd, Momordica charantia Linn. Pest Management In Horticultural Ecosystems, 17(1), 23-27.

USDA National Nutrient data base.

Viraktamath, S., and Anagoudar, J. (2002). Influence of bee attractants in enhancing pollination and yield parameters in Cucumis sativus L. Indian Bee J, 64(1-2).

\section{How to cite this article:}

Yogapriya, A., B. Usharani, K. Suresh, S. Vellaikumar and Chinniah, C. 2019. Foraging Behaviour of Major Pollinators in Bitter Gourd. Int.J.Curr.Microbiol.App.Sci. 8(06): 947-954. doi: https://doi.org/10.20546/ijcmas.2019.806.114 